\title{
PPAR Yリガンドを用いた非アルコール性 脂肪性肝炎（NASH）の治療戦略
}

\author{
米田 正人 ${ }^{1)}$, 藤田 浩司 ${ }^{1)}$, 中島 淳 $^{1)}$, 和田孝一郎 ${ }^{2)}$
}

要約：非飲酒者でも脂肪肝に肝実質の壊死，炎症，線 維化所見が加わった非アルコール性脂肪性肝炎（nonalcoholic steatohepatitis：NASH）に対する関心が我 が国でも急速に高まっている.NASH の治療は栄養療 法の徹底が重要であり, 難治症例には薬物療法が検討 される.我々は当院に通院する NASH 患者に施行し た栄養指導，またピオグリタゾンを用いた薬物療法の 有効性を検討した。【方法】 NASH 患者に管理栄養士 の指導の下，標準体重 $\times 25 \mathrm{kcal} / \mathrm{kg} /$ 日, タンパク質 1.0-1.5 g/ 標準体重 /日, 脂肪量 20\% 以下の栄養指導 を行った。また栄養療法が奏功しない症例に薬物療法 としてピオグリタゾン $15 \mathrm{mg} /$ 日の投与を行った。ま た治療前後で肝臓と脾臓の CT 值比率 ( L/S 比) およ び臨床データの比較検討を行った. 約 6 割の症例は栄 養療法のみで臨床データの改善を認めた. L/S 比は前 0.961 後 $1.190(P=0.0002)$. フェリチン值と高感度 CRP の栄養指導前後の変化率 $\Delta$ フェリチン值と $\Delta \mathrm{hs}$ $\mathrm{CRP}$ は $\Delta \mathrm{L} / \mathrm{S}$ と強い相関を示し, 治療効果判定に有効 であることが示唆された。また栄養療法に難治した 20 症例に対しピオグリタゾンの投与が行われたが, 脂肪肝の著明な改善と肝機能の改善を得られた。また 薬物による副作用は本件等では認められなかった。 NASH や NAFLD の治療は生活習慣の改善や肥満の解 消が原則である。しかし，体重コントロールに苦慮す ることや，肥満を伴わない NASH が存在することよ り減量指導のみでは不十分であり, ピオグリタゾンは NASH の治療に有用であることが示唆された。

\section{1.はじめに}

近年，日本においてもライフスタイルの欧米化によ り健診で脂肪肝と診断される割合は人口の約 3 割と増
加している. 脂肪肝の主な成因としては肥満, 糖尿病 に由来する過栄養性やアルコール性があげられ, 非ア ルコール性の脂肪肝 (non-alcoholic fatty liver disease：NAFLD）は従来可逆性，良性の疾患とされて きた。しかし 1980 年に Ludwigら (1) が，飲酒歴が ないにも関わらず肝組織がアルコール性肝障害に類似 する疾患概念を非アルコール性脂肪性肝炎（non-alcoholic steatohepatitis：NASH）として提唱し，その後 1998 年 NIH でNASH の疾患概念の重要性が宣言され 脂肪肝は新しい局面を迎えたといえる。 NASH は 10 年間で約 2 割が肝硬変へ進展し, 時に肝細胞癌に至る 疾患であり (2), 現在肥満人口の増加を反映し日本で も国民の約 3\% が NASH に罹患していることが想定さ れている (3).

NAFLD の一種である NASH の治療は食事療法，運 動療法が基本である。しかし食事療法，運動療法によ つて効果が得られない場合，薬物療法が試みられてい る. 本稿では横浜市立大学にて肝生検を行い NASH と診断した症例に対し食事療法や PPAR $\gamma$ リガンドで あるピオグリタゾンを用いた薬物療法を検討したので 提示する。

\section{PPARとは}

\section{1) PPAR yの歴史}

ペルオキシゾーム増殖殽活性化受容体 (peroxisome proliferators-activated receptor：PPAR）は脂質，糖代 謝の重要な制御物質である。PPAR はステロイドホル モン受容体ファミリーに属する核内受容体である $(4,5)$. 1990 年にマウス肝臓 cDNA ライブラリーから PPAR がクローニングされた。その後，ノックアウトマウス の作成とその表現型の解析により, PPARの in vivo の

キーワード : NASH, NAFLD, 食事療法, 薬物療法, PPAR $\gamma$

1) 横浜市立大学大学院医学研究科 分子消化管内科学（７236-0004 横浜市金沢区福浦 3-9)

e-mail : yoneda@med.yokohama-cu.ac.jp＼cjkstart原稿受領日：2006 年 7 月 18 日, 会誌編集委員会依頼原稿

2) 大阪大学大学院歯学研究科 薬理学 ( $5565-0871$ 吹田市山田丘 1-8)

Titile: PPAR $\gamma$ ligand pioglitazone as a therapeutic strategy in nonalcoholic steatohepatitis (NASH)

Author: Masato Yoneda, Koji Fujita, Atsushi Nakajima, Koichiro Wada 
表 $1 \mathrm{NASH}$ か単純性脂肪肝かを規定するロジスティック回帰分析

\begin{tabular}{lcc}
\hline & $P$ 值 & $95 \% \mathrm{CI}$ \\
\hline 年齢 & 0.3071 & $0.863-1.073$ \\
性別 & 0.0409 & $0.429-276.391$ \\
HDL レステロール & 0.0461 & $1.005-1.171$ \\
LDL コレステロール & 0.8539 & $0.969-1.017$ \\
血小板 & 0.1493 & $0.884-1.378$ \\
アルブミン & 0.6316 & $0.048-292.269$ \\
フェリチン & 0.0309 & $0.858-0.990$ \\
高感度 CRP (mg/l) & 0.0258 & $0.032-0.243$ \\
4 型コラーゲン 7s & 0.4581 & $0.425-3.701$ \\
ヒアルロン酸 & 0.3824 & $0.982-1.038$ \\
コリンエステラーゼ & 0.3101 & $0.990-1.025$ \\
BMI & 0.0714 & $0.822-1.537$ \\
\hline 線維化の重症度を規定するロジスティック回帰分析 & \\
\hline & $P$ 值 & \\
\hline 年齢 & 0.5961 & $95 \% \mathrm{CI}$ \\
性別 & 0.149 & $0.865-1.288$ \\
プロトロンビン時間 & 0.495 & $0.200-39951.15$ \\
血ホ板 & 0.0893 & $0.959-1.796$ \\
アルブミン & 0.1552 & $0.257-5016.056$ \\
高感度 CRP (mg/l) & 0.0147 & $0.012-0.615$ \\
4 型コラーゲン 7s & 0.0561 & $0.049-1.040$ \\
ヒアルロン酸 & 0.5811 & $0.947-1.031$ \\
BMI & 0.6898 & $0.755-1.528$ \\
\hline & & \\
\hline & & 4.287 \\
\hline
\end{tabular}

役割が解明されつつある。

\section{2) PPARの種類とその役割}

PPARには $\alpha, \delta(\beta), \gamma$ という 3 つのサブタイプ が存在する.PPAR $\alpha$ は肝細胞にきわめて多く存在する. 代表的なリガンドとしてべザフィブラートなどのフィ ブラート系高脂血症剤や遊離脂肪酸があげられる。 PPAR $\gamma$ は脂肪細胞に多く存在し, 脂肪酸のトリグリ セライドの変換や唄蔵に関与している。肝臓では星細 胞（伊東細胞）に比較的多く存在する．ピオグリタゾ ンなどのインスリン抵抗性改善薬であるチアゾリジン 誘導体が有名である. PPAR $\delta$ も肝蔵に多く存在し, 星細胞に多いとの報告がある.

\section{NASH患者の治療戦略}

\section{1) NASH 症例 (78 症例) から見た臨床特徵の検討}

従来より良性の脂肪肝と NASH は血液検査や各種 画像データでは鑑別ができないことが知られている $(6$, 7). NASH の診断確定, 進行度評価のためには肝生検 に頼らざるを得ない(8) ため，NASH の診断を困難に している.

横浜市立大学消化器内科で 2004 年 1 月から 2006 年 1 月にNASH を疑い肝生検を施行した NAFLD 症例 78 例の臨床的な特徵を検討した。肝生検での結果は
単純性脂肪肝 16 例，NASH 患者 62 例であった。 NASH 患者をBrunt の分類 (9) により stage1，2 の症 例を線維化軽症例， stage3，4 の症例を線維化進行症 例と 2 群に分類すると線維化軽症例は 47 症例, 線維 化進行症例は 15 症例であった。年齢，性別を調節し たロジスティック回帰分析を施行し，単純性脂肪肝患 者，NASH 患者を規定する因子，また線維化の軽症例， 進行例を規定する因子の検討をおこなった（表 1).

NASH を規定する因子として, HDL コレステロール の低下, 血清フェリチン值の上昇, 高感度 CRP の上 昇が認められ，また線維化の重症度を規定する因子と して高感度 CRP が認められた。この結果は, 診断, 進行度の判定に侵襲的な肝生検しかない NASH の病 態に対する非侵襲的な診断法として有用である可能性 を示唆している.

\section{2) NASH，NAFLD に対する治療戦略}

肝生検により NASH と診断された 64 名に対し，全 例に管理栄養士の指導の下で 3 力月の栄養指導を拀こ なった。栄養指導は摂取するエネルギーと脂肪の減量 を主眼とし，エネルギーは標準体重あたり 1 日に 25 $\mathrm{kcal} / \mathrm{kg}$ とし, 脂肪量は全エネルギーの $20 \%$ 以下（健 常者の食事では $21 ２ 8 \%$ ）とした。また蛋白は 1 $1.5 \mathrm{~g}$ / 標準体重 $\mathrm{kg}$ /day とした。 

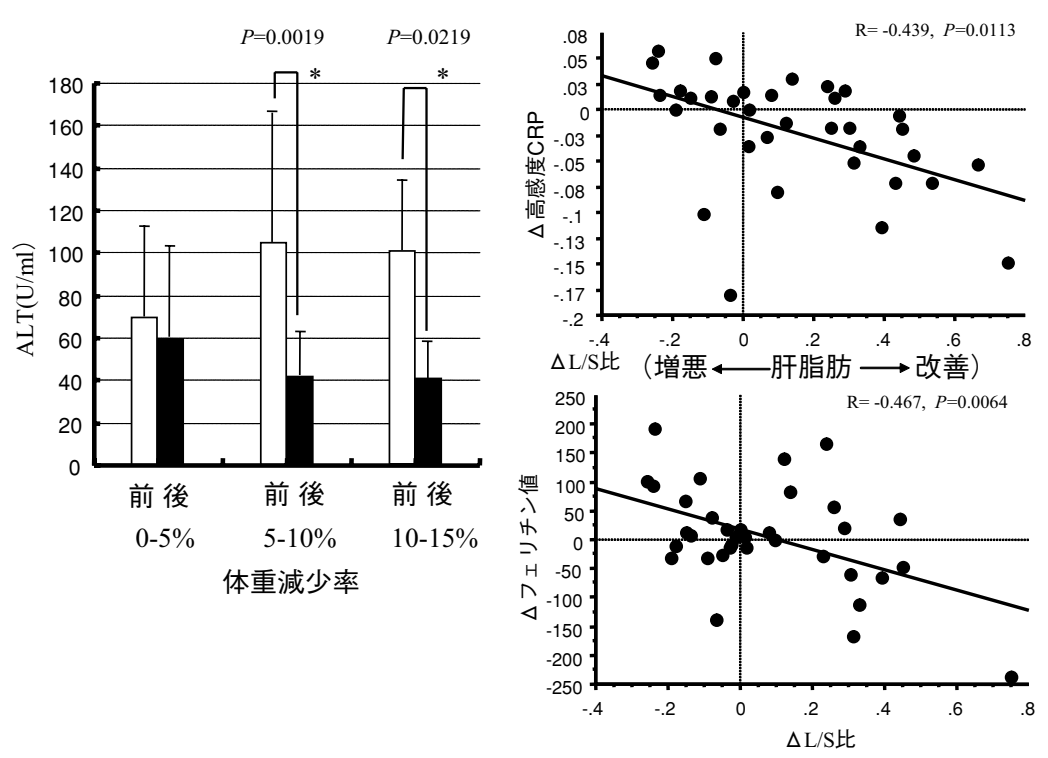

図 $1 \mathrm{NASH}$ 患者に対し 1 年間の栄養指導を行った体重減少と肝機能の改善の関係（左） 脂肪肝の改善と高感度 CRP, 血清フェリチン值の関係 (右)

3 力月の栄養指導で体重減少，肝機能の改善など効 果の認めた症例においては 1 年間の栄養指導を継続し, 効果の認めなかったものに対しては薬物療法としてピ オグリタゾン $15 \mathrm{mg} /$ 日の投与を行った.

\section{(1) NASH 患者に対する栄養療法}

NASH の重要な病因の 1 つであるインスリン抵抗性 は，体重減少によって改善することが報告されている $(10,11)$ 。また肥満症がある場合, 内臟脂肪の過剩は インスリン抵抗性，高インスリン状態を生み出し，そ の結果, 肝細胞内での中性脂肪の合成が充進する。図 2 は 1 年間の栄養指導を施行した NASH 患者の肝機能 異常の動向を調べたものだが， 1 年間で $5 \%$ 以上の体 重減少に成功した NASH 患者では有意に肝機能の改 善を認めた（図 1)。また肝臟の脂肪化に対する客観 的な指標として肝臟と脾臟の CT 值比 (12) (Liver to spleen ratio：L/S 比）を用い， 1 年間の栄養指導を行 い脂肪肝の改善程度を $\mathrm{CT}$ 值での肝臓 / 脾臓比率変化 $\Delta \mathrm{L} / \mathrm{S}$ （栄養指導後の $\mathrm{L} / \mathrm{S}$ 比 - 前の $\mathrm{L} / \mathrm{S}$ 比）を用いて 評価すると $\Delta$ 高感度 $\mathrm{CRP}, \Delta$ フェリチン值と極めて強 い相関をみとめ（図 1), NASH 患者における栄養指 導の効果判定として高感度 CRP, 血清フェリチン值 を用いると有効であることが示唆された。

\section{(2) NASH の薬物療法}

インスリン抵抗性，およびメタボリックシンドロー ムの存在が NASH の病態を像悪させることは多くの 検討により報告されてきた.インスリン抵抗性改善薬
として 2 型糖尿病患者に使用されているチアゾリジン 誘導体は NASH 加療に関しても有望な薬剤である. 現在わが国で使用可能なチアゾリジン誘導体はピオグ リタゾンのみであるが，アメリカでのパイロット試験 により 48 週間のピオグリタゾン投与が病理組織上でも, NASH の病態を改善させたことが報告された(13)。ま た同様に日本では重篤な肝障害のため発売中止になっ たが rosiglitazone でも同様に 48 週間投与により NASH 改善効果が報告されている (14)．横浜市立大学 でNASH 患者 20 症例に対して 12 カ月のピオグリ夕 ゾン $15 \mathrm{~m} /$ 日を投与した検討を提示する（図 2). 肝 細胞内の脂肪化を定量する $\mathrm{L} / \mathrm{S}$ 比は投与後にほぼ正 常領域となっており, トランスアミナーゼも有意に改 善した。またデー夕は割愛するが，HDLコレステロ ール, 高感度 CRP, HbAlc の低下を認め, 体重増加や, 薬剤性肝障害などの副作用は認めなかった。

\section{4. 考察}

肥満による脂肪肝は日常よく遭遇する疾患であるも のの，患者自身の症状がほとんどなく未治療の場合も 少なくないと思われる．近年ライフスタイルの欧米化 に伴い, 日本でもメタボリックシンドロームは急増し ている，メタボリックシンドロームに扔ける肝臓の役 割は重要であり, 将来的には個々の患者の特性を捉え たうえで, 運動療法, 食事療法, 薬物療法を独自に組 み合わせた多岐に渡る治療法の中から, 個々の患者に 

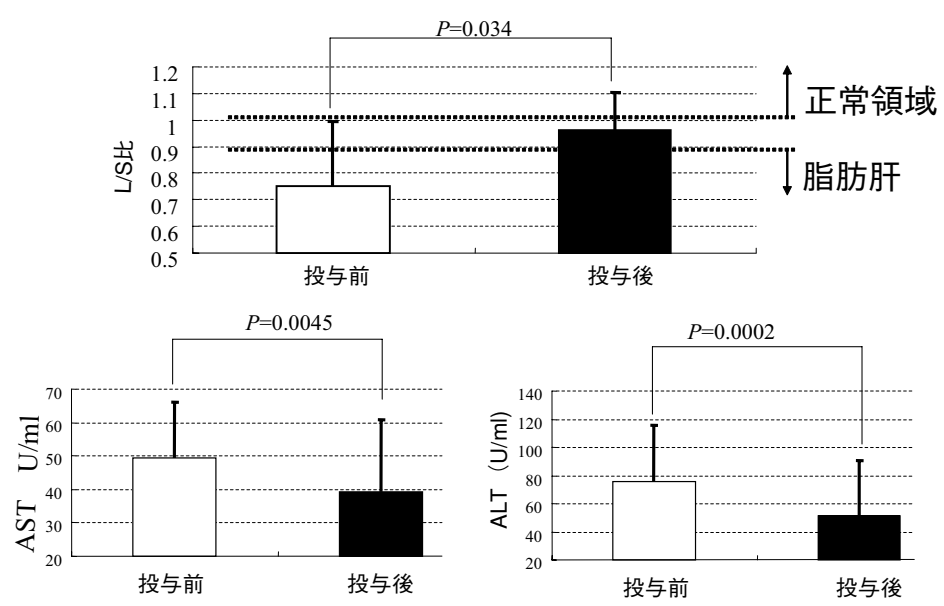

図 $2 \mathrm{NASH}$ 患者にピオグリタゾン $15 \mathrm{mg} /$ 日の薬物療法を施行した脂肪肝, 肝機能の改善 $(n=20)$

適した治療法を選択していくような治療法の確立が望 まれる. NASH や NAFLD の治療は生活習慣の改善や 肥満の解消が原則である。しかし，体重コントロール に苦労することや，肥満を伴わない NASH が存在す ることより減量指導のみでは不十分である。ピオグリ タゾンはインスリン抵抗性改善薬として成人型糖尿病 に用いられており，NASH 患者において改善効果が pilot study として報告されているが本検討により， NASH の発生要因の異なると考えられる日本人にも有 効である可能性が示唆された。

\section{文献}

1) Ludwig J, et al. Mayo Clin Proc. 1980;55:434-438.

2) Matteoni CA, et al. Gastroenterology. 1999;116:1413-1419.

3）西原利治, 他. 日内会誌. 2003;92:1104-1109.

4) Desvergne B, et al. Endocr Rev. 1999;20:649-688.

5）田中直樹, 他 . 日内会誌 . 2001;90:2033-2039.

6) Neuschwander-Tetri BA. Can J Gastroenterol. 2000;14:321326.

7) Reid AE. Gastroenterology. 2001;121:710-723.

8) Saadeh S, et al. Gastroenterology. 2002;123:745-750.

9) Brunt EM. Semin Liver Dis. 2004;24:3-20.

10) Busettto L. Nutr Metab Cardiovasc Dis. 2001;11:95-204.

11) Oneta C, et al. Swiss Med Wkly. 2002;132:493-505.

12) Wasnich R, et al. J Nucl Med. 1979;20:149-154.

13) Promrat K, et al. Hepatology. 2004;39:188-196.

14) Neuschwander-Tetri BA, et al. Hepatology. 2003;38:10081017.

\section{著者プロフィール}

\section{米田 正人（よねだ まさと）}

横浜市立大学附属病院 消化器内科, 助手, 医学博士.

$\diamond 1995$ 年横浜市立大学医学部入学, ’ 01 年卒業, 横浜市立大学大学院医学研究科入学, ’05 年卒業, 医学博士号取得, 同年 11 月横浜市立大学附属病院消化器内科, 助手. 研究テーマ: 非アルコール性脂肪性肝炎 (NASH), 自己免 疫性肝炎 $(\mathrm{AIH})$ ○趣味：テニス，スポーツ鑑賞。

$\diamond$ 主な論文 : (1)日本臨床 . 2006;64(6):1139-1145. (2)肝胆腪 . 2005;51(5):827-835. (3) Medical Practice. 2005;22(10):17311736. (4) 日本内科学誌. 2006;95(1):76-81. (5)アルコールと医学生物学. 2005;25:75-78. (6) 日本臨床. 2005;63(4)665-671. (7)内分泌 · 糖尿病科 . 2003;17(3):230-235. 8)消化器科 . 2002;35(4):432-438.

藤田 浩司（ふじた ひろし）

横浜市立大学大学院医学研究科 分子消化管内科学, 大学院生.

$\diamond 1995$ 年横浜市立大学医学部入学, ’02 年卒業, ’04 年横浜市立大学大学院医学研究科入学. $\searrow$ 研究テーマ：非アル コール性脂肪性肝炎 (NASH). 趣味：テニス.

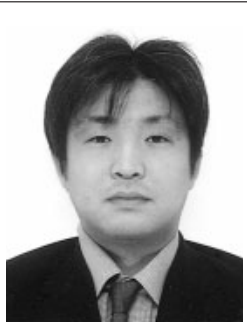

中島 淳 本誌 122 巻 4 号 316 頁（2003）をご参照下さい. 和田孝一郎 本誌 122 巻 4 号 308 頁（2003）をご参照下さい. 